\title{
Türkiye İçin Bir Taşınmaz Değerleme Sistemi Yaklaşımı
}

\author{
Nuri ERDEM ${ }^{1 *}$ \\ ${ }^{1}$ Osmaniye Korkut Ata Üniversitesi, Mühendislik Fakültesi, Harita Mühendisliği Bölümü, Osmaniye \\ (nurierdem@oku.edu.tr)
}

\begin{abstract}
Öz
İyi işleyen bir taşınmaz değerleme sisteminin tesis edilmesi ve sürdürülmesi ülke yönetimlerinin en önemli görevlerinden biridir. $\mathrm{Bu}$, gerek adaletli vergilendirmenin sağlanması gerekse farklı uygulamalarda ihtiyaç duyulan değerlerin sağlıklı bir şekilde oluşturulabilmesi açısından önem taşımaktadır. Bu bağlamda, bu çalışmada, ülkemizdeki taşınmaz değerleme sisteminin mevcut durumu araştırılmış ve sistemin sağlıklı işleyen bir yapıya kavuşturulabilmesi için bir yaklaşım geliştirilmiştir. Çalışmaya ilk olarak ülkemizin taşınmaz değerleme sisteminin mevzuat, kurumsal ve teknik yapısının incelenmesiyle başlanmıştır. Taşınmaz değerleme sistemimizin mevcut durumunu ortaya koymak amacıyla, ülkemizde değerlemeyle ilgili faaliyet yürüten kurumların il, bölge ve genel müdürlüklerindeki idareci ve çalışanlarla ve özel sektör değerleme uzmanlarıyla mülakatlar gerçekleştirilmiştir. Özellikle değerleme alanında iyi uygulamaya sahip ülkelerden Almanya, Hollanda, Danimarka, İsviçre, İngiltere ve ABD başta olmak üzere diğer bazı ülkelerin sistemleri araştırılmıştır. Bu mülakat ve araştırmalardan elde edilen bulgulardan da yararlanılarak, ülkemiz için mevzuat, kurumsal ve teknik bileşenleri içeren bir Türkiye Taşınmaz Değerleme Sistemi (TADES) yaklaşımı geliştirilmiştir.

Bu yaklaşımda; değerlemenin yasal altyapısının çerçeve bir "Taşınmaz Değerleme Kanunu" altında yeniden düzenlenmesi, bu Kanunun değerleme uzmanlarına yol gösterici diğer düzenleme ve rehber dokümanlarla detaylandırılması, değerleme faaliyetlerini düzenleyen, yöneten ve denetleyen bir "Taşınmaz Değerleme Genel Müdürlügü̆”nün (TDGM) tesis edilmesi, toplu değerleme çalışmalarının lisanslı değerleme şirketlerinden de destek alınarak belediyeler tarafından gerçekleştirilmesi, gerek kamu gerekse özel sektörce gerçekleştirilen tekil ve toplu değerlemelerde kullanılmak üzere taşınmaz karakteristikleri ve emsal satışlar veritabanlarının oluşturması ve sürdürülmesi önerilmektedir.
\end{abstract}

Anahtar Kelimeler: Taşınmaz Değerleme, Türkiye Taşınmaz Değerleme Sistemi, Yeniden Yapılanma.

\section{An Approach for Turkish Real Estate Valuation System}

\begin{abstract}
One of the most important tasks of the governments throughout the world is establishment of the wellfunctioning real estate valuation systems. This provides both equitable taxation and availability of the healthy values required in different applications. In this context, this paper evaluates current situation of the Turkish real estate valuation system and proposes an approach to establish well-functioning system in the country. It begins with an evaluation of the current system based on legal, institutional and technical aspects. The evaluation is carried out in terms of the interviews and surveys performed with managers and employees of the organizations doing real estate valuations in both public and private sectors in the country. It clearly shows that there is need for re-engineering in the real estate valuation system in Turkey. The study also inves-tigates real estate valuation systems of Germany, the Netherlands, Denmark, Switzerland, United Kingdom, United States and some others as well-functioning systems. As a result, it proposes an approach for The Turk-ish Real Estate Valuation System considering the findings of the interviews and case study researches. Accord-ing to this approach, "The Law on Real Estate Valuation" supported by required regulations and guiding doc-uments
\end{abstract}

\footnotetext{
* Sorumlu Yazar

Bu makale; Yük. Müh. Nuri ERDEM'in 2016 yılında Erciyes Üniversitesi Fen Bilimleri Enstitüsü Harita Mühendisliği Anabilim Dalında tamamlanan ve "Türkiye İçin Bir Taşınmaz Değerleme Sistemi Yaklaşımı " isimli doktora tez çalışmasından üretilmiştir.
} 
should be enacted as a legal basis of the valuation works, "The General Directorate of Real Estate Valuation" should be established as a leading institution in the domain to organize, manage and supervise the valuation works throughout the country, mass appraisal works should be carried out by the municipalities with support of licensed companies of real estate valuation, real estate characteristics and sales prices databases should be established and sustained to use in both single and mass valuation works by the public and private sector experts.

Keywords: Real Estate Valuation, Real Estate Valuation System of Turkey, Re-engineering.

\section{GÍRIŞ}

Vergilendirme, kamulaştırma, özelleştirme, tescile esas işlemler, irtifak hakkı tesisi gibi kamusal uygulamalar ile sermaye piyasası, bankacılık, kredilendirme, sigortacılık gibi özel sektör uygulamalarında taşınmaz değerlerine ihtiyaç duyulmaktadır. Bu nedenle, gerek taşınmaz pazarlarının şeffaflığının sağlanabilmesi gerekse kamu ve özel sektör değerleme uygulamalarının adil bir şekilde gerçekleştirilebilmesi için ülkelerin iyi işleyen değerleme sistemlerini oluşturmaları ve sistemlerini zaman içinde ortaya çıkabilecek ihtiyaçlar çerçevesinde revize etmeleri önem arz etmektedir (Çete, 2008).

Ülkemizdeki taşınmaz değerleme sisteminin mevzuat, kurumsal ve teknik anlamda yeniden yapılanmasıyla ilgili bilimsel anlamda daha önceden yapılmış çalışma ve önerilerden bazıları yıl bazlı olarak aşağıda özetlenmektedir.

Açlar vd. (2003)'e göre; Harita ve Kadastro Mühendisleri Odası (HKMO) öncülügünde ve koordinasyonunda "Taşınmaz Değerleme ve Yönetimi Yüksek Kurulu” (TDYÜK) gibi isim- lendirebileceğimiz bir kurul oluşturulması, terminolojide, ilkelerde, yöntemlerde, veriler- de ve belgelerde standart sağlanmasına çal1- şılması yerinde olacaktır. Yüksek Kurul ba- ğımsız yetkisini, TMMOB Yasası'nda yapıla- cak bir düzenlemeden ya konuya ilişkin var olan yasalarımız incelenerek düzenlenecek yasa gücünde kararname ya da ayrı bir yasa- dan alarak; ülke taşınmaz piyasasını düzenle- yen ve yönlendiren TKGM, SPK, Arsa Ofisi Genel Müdürlüğü, belediyeler ile kamu kurumları ve yerel yönetimlerdeki değerleme komisyonlarıyla etkileşimli çalışmalıdır.

Çağdaş (2007)'e göre; Ülkemiz emlak vergi sistemindeki problemlere çözüm önerisi olarak, vergi sisteminin gereksinim duyduğu teknik altyapı üzerinde durulmuştur. Yeni kamu sicillerinin oluşturulması önerilmiş; ülkemiz kadastral sisteminin önerilen sicillerle desteklenerek toprak-arazi yönetimi için gerek duyulan bilgi altyapısının oluşturulması görüşü savunulmuştur. Buna göre, taşınmazlara ilişkin mülkiyet bilgileri kadastral sistemden, kullanım ve değerleme-vergilendirme bilgileri ise önerilen sicillerden sağlanacaktır. Tasarım modelinde toplu değerleme sistemine geçiş önerilmiş; bu amaçla süreçte görev alması olası aktörler tanımlanmış; değerlemede kullanılacak veri türleri ve verilerin edinim yolları belirlenmiş; değerleme süreci modellenmiş; diğer değerleme uygulamalarında da yararlanılacak Ulusal Değerleme Veri Tabanının kurulması önerilmiştir. Vergi tarhiyatı süreci de tanımlama ve değerleme alt sistemlerindeki önerilere göre yeniden düzenlenmiştir.

Çete (2008)'e göre; Ülkemizde arazi idaresinin lider kurumunun "Arazi İdaresi Müsteşarlığı” (AİM) gibi bir ad altında güçlü bir kurumsal yapılanmaya sahip olması ve tapu, kadastro, harita yapımı ve taşınmaz değerlemesi gibi arazi idaresi faaliyetlerini bünyesinde bir araya getirmesi önerilmektedir. AIM; ilgili alanlardaki genel müdürlüklerden ve ihtiyaç duyulan taşra teşkilatı yapılanmalarından oluşmalıdır. Bu yaklaşımla, AİM'in Genel Müdürlüklerinden birisinin de Taşınmaz Değerlemesi Genel Müdürlüğü şeklinde yapılandırılması ve taşınmaz değerlemesi faaliyetlerinin bütüncül bir yapıda ve uzman bir kurumca gerçekleştirilmesi önerilmektedir.

Yomralığlu (2009)'a göre; Taşınmaz değerlemesi ile ilgili yasal mevzuat ve kurumsal değer belirleme kargaşası, hem değerleme işleminin yetkili tek bir kuruma verilmesini hem de yeni bir yasal değerleme tüzüğüne ihtiyacı gerektirmektedir. Bu bağlamda ilgili kamu kurumları ile çift yönlü veri alışverişinde bulunacak ve veriyi kendi bünyesinde tutacak, gerekirse pazarlayacak bir Gayrimenkul Değerleme Kurumuna (GDK) ihtiyaç vardır.

Uzer (2009)'a göre; Ülkemizde taşınmaz değerlemesi faaliyetlerinde yaşanan mevcut 
yasal dağınıklığın giderilebilmesi ve uygulamalarda uluslararası değerleme standartlarının sağlanabilmesi için değerleme faaliyetlerini düzenleyen bir "Taşınmaz Değerleme Yasası"na ve lider bir kuruma ihtiyaç vardır. Lider kurum, ana görevi taşınmazları hukuki ve teknik yönleriyle kayıt altında tutmak olan, Tapu ve Kadastro Genel Müdürlüğü olmal1dır. TKGM'nin 3045 sayılı Teşkilat Kanunu'nda yapılacak düzenlemeyle TKGM bünyesinde "Taşınmaz Değerleme Dairesi Başkanlığı" birimi ve TKGM bünyesindeki 22 adet bölge müdürlüğünde "Taşınmaz Değerleme Şube Müdürlüğü” oluşturulabilir. Alımsatım işlemlerinde harca esas değerin doğru beyan edilebilmesi için, bu işlem için gerekli belgeler arasında, satışı yapılacak taşınmaza ait, içinde bulunulan yılda, Lisanslı Değerleme Uzmanı tarafından hazırlanmış "Ekspertiz Raporu" da bulunmalıdır. Ülkedeki tüm kamulaştırma, özelleştirme ve mahkemeler gibi kamusal alanda gerçekleştirilen değerleme faaliyetlerine ilişkin değer verileri ve Tapu Müdürlükleri'nde gerçekleştirilen alım-satım değerleri, TKGM Bölge Müdürlükleri bünyesindeki Taşınmaz Değerleme Şube Müdürlükleri tarafindan bir veritabanında toplanarak, "Değer Verisi Havuzu" oluşturulmalıdır.

Çağatay (2008)'e göre; Türkiye'de taşınmaz değerlemesi alanında önemli bir boşluğu dolduracak olan Taşınmaz Değerlemesi Bilgi Sistemi (TADEBİS) için kurumsal ve teknik bir yapılanmaya ihtiyaç bulunmaktadır. Kurumsal açıdan taşınmaz değerlemesinden sorumlu olacak kurum, kamu kontrolünde ve özel sektör paylaşımlı olmalıdır. Örgüt yapısı olarak ise merkez ve il düzeyinde örgütlenen taşra birimlerinden oluşmalıdır. Merkez teşkilatının yönlendirici olmasının yanında değer oluşum süreçlerini taşra birimlerine bırakması daha uygundur. Bunun sebebi, taşınmaz piyasalarının yerel olması, değerlemeyi oluşturan verilere taşrada daha kolay ulaşılabilmesi gibi faktörlerdir. Oluşturulması gereken Taşınmaz Değerleme Kurumu, TADEBİS uygulamasını temsil edecek kurum olmalıdır.

Değirmenciler (2008)'e göre; Etkin bir taşınmaz değerleme sistemi için Değer İzleme Sistemi kurulmalıdır. Değer hareketlerinin anlık izlenebilmesi için gayrimenkulün bulunduğu bölgede bulunmak gerekmektedir. $\mathrm{Bu}$ yüzden değer izleme sistemi, merkezden yönetilen yerel ağların bir toplamı olmalıdır. Kurumlar arasındaki işbirliğinde; Maliye $\mathrm{Ba}$ - kanlığı, Tapu ve Kadastro Genel Müdürlüğü ve Belediyeler öne çıkmaktadır. Her ay bir ilçede oluşan değerler yerel maliye teşkilatı tarafindan toplanacak ve ay sonunda merkez birime bildirilecektir. İlgili ay içinde o ilçede mahkemelerce yapılan kamulaştırma ve kira takdirleri, Hazineye ait taşınmazlara ilişkin takdirler, banka kredisine esas değer takdirleri, belediyelerin yaptığ 1 tüm takdirler bu kapsama dahildir. Yerel maliye teşkilatı eline ulaşan bu değerleri arsa, arazi, bina ve konut anlamında ayrıştıracak ve o şekilde merkeze gönderecektir. Bu bilgiler CBS uyumlu bir değer haritasının oluşumuna altlık oluşturacaktır. Yerel maliye teşkilatı, o ilçede Tapu Sicil Müdürlüğünde yapılan işlemleri de aylık olarak alacaktır. Değerlerin veri olarak depolanması birçok kamu kurumunun uygulamalarında yol gösterici olacaktır.

Hacıköylü (2009)'a göre; Emlak vergisinde yaşanan değer tespitine ilişkin sorunlar mevzuattan, idareden ve mükelleften kaynaklanan sorunlardır. Mevzuattan kaynaklanan sorunların çözümü için; mülkiyet kadastrosu anlayışının terk edilerek mali kadastro anlayışının benimsenmesi gerekir. Böylece vergisel amaçlı taşınmaz değerlemesi önem kazanacak, taşınmaz satış veri tabanının oluşturulması ve CBS'nin bu açıdan kullanılması sağlanabilecektir. İdareden kaynaklanan sorunların çözümü için, belediyelerde vergi inceleme yetkisine sahip personel istihdamı sağlanma- lıdır. Böylece emlak vergisinin yönetimi daha etkin olabilecek ve vergi kayıp ve kaçakları da önlenebilecektir. Emlak vergisinde mükellef- ten kaynaklanan sorunlar daha çok verginin tahsil aşamasında yaşanmaktadır. Çözüm için mükelleflerin vergiye gönüllü katılımını artı- rabilecek bir takım düzenlemelerin yapılması gerekir. $\mathrm{Bu}$ amaca yönelik ise çalışmada em- lak vergisine ve tapu kadastro harçlarına iliş- kin bir takım önerilere yer verilmiştir. Emlak vergisine ilişkin olarak vergi oranlarının düşü- rülmesi, tespit edilen değerlere karşı mükelle- fe itiraz hakkının tanınması, emlak vergisinde mükellefin gönüllü katılımını artırabilecektir. Ayrıca tapu ve kadastro harçlarının kaldırılması veya oranlarının düşürülmesi mükelleflerin alım satıma konu taşınmazlarının gerçek değerini beyan etmesi açısından önem taşımaktadır. 
Candaş (2012)'ye göre; Taşınmaz değerlerini kayıt altında tutacak olan kurumun, ülkemizde taşınmazları kayıt altına alan ve mülkiyet haklarının güvence altına alan kurum olan Tapu ve Kadastro Genel Müdürlüğü (TKGM) olması doğru olacaktır. Taşınmaz Değerlemesi faaliyetlerini yürütmek amaciyla TKGM altında Taşınmaz Değerlemesi Daire Başkanlığı kurulmalıdır. Taşınmaz değerlemesi faaliyetlerinin standardize edilmesi, işlemlerin tek elden yürütülmesi ve denetlenmesi, taşınmaz değerlerinin kayıt altına alınması ve taşınmaz piyasasındaki dalgalanmaların kontrol altına alınması, kurumlardaki işlem tekrarlarının ve farklılıklarının ortadan kaldırılması ve benzeri sebeplerden ötürü ülkemizde bir Taşınmaz Değerlemesi Kanunu'na olan ihtiyaç da ortadadir.

Y1ldız (2014)'e göre; Toplu değerleme faaliyetlerinin, tekil değerleme işlemlerini de yapan, yaptıran, denetleyen, düzenleyen bir üst kurul eli ile yürütülmesi gerektiği değerlendirilmektedir. Toplu değerleme sisteminin ihtiyaç duyduğu ilk temel bileşen değer/fiyat bilgileridir. Toplu değerleme sisteminin kurulabilmesi için gereken birinci koşul satış işlemlerinde gerçekleşen fiyat bilgisinin doğru olarak, ayrıntılı bilgileri ile birlikte tutulduğu TAKBIS ile entegre ortak bir veritabanının oluşturulmasıdır. Böylece bu bilgiler toplu değerleme sistemi içinde model oluşturma amaçlı olarak kullanılabilecektir. İşlemlerde gerçekleşen fiyat bilgilerinin doğru olarak beyan edilmesi için, ilk y1llarda harç oranının düşürülmesi gibi teşvik edici önlemlerin alınmas1 önem arz etmektedir. Toplu değerleme sisteminin ihtiyaç duyduğu ikinci temel bileşen, taşınmazların değerine etki eden öz nitelik bilgileridir. $\mathrm{Bu}$ verilerin, kurumlar aras1 veri paylaşımı ile elde edilebileceği düşünülmektedir. Toplu değerleme sisteminin ihtiyaç duyduğu üçüncü temel bileşen, yetişmiş insan kaynağıdır. Toplu değerleme sistemi kuruluşunda, personel maliyetini düşürmek amacıyla, İngiltere'de değerleme ofisince yapıldı̆̆ gibi kamu kurumları ve üniversitelerde çalışan yetişmiş iş gücünden faydalanılabileceği düşünülmektedir.

Yapılan çalışmada, Türkiye taşınmaz değerleme sisteminin mevcut durumu incelenmiş ve ülkemizde değerleme alanında sağlıklı bir mevzuatın ve kurumsal yapılanmanın bulunmadığı, değerlemede ihtiyaç duyulan veri tabanlarının ve değerleme modellerinin de oluşturulamadığ1 görülmüştür. Bu nedenle, gerek vergilendirme amaçlı gerekse diğer amaçlarla gerçekleştirilen değerleme çalışmalarının sağlıklı bir yapıda yürütülebilmesi için ülkemize özgü iyi işleyen bir değerleme sistemi yaklaşımının geliştirilmesi hedeflenmiştir. $\mathrm{Bu}$ kapsamda, değerleme uzmanlarıyla mülakatlar gerçekleştirilmiş ve uzmanların mevcut yapı hakkındaki düşünceleri ve yeni sistemden beklentileri araştırılmıştır. Ayrıca, taşınmaz değerlemesinde iyi uygulamaya sahip ülkelerden, Türkiye'ye model olabilecek bazı yasal, kurumsal veya teknik özellikleri bünyesinde barındıran ülkeler belirlenerek, bu ülkelerin değerleme sistemleri incelenmiştir. Gerek değerleme uzmanlarıla yapılan mülakatlardan gerekse iyi uygulamalar araştırmasından elde edilen bilgi ve bulgulardan yararlanılarak, Türkiye için bir taşınmaz değerleme sistemi yaklaşımı geliştirilmiştir. Elde edilen bulgular ve geliştirilen yaklaşım aşağıda alt başlıklar halinde özetlenmektedir.

\section{TÜRKIYYE TAŞINMAZ DEĞERLEME SISTEMI}

$\mathrm{Bu}$ bölümde, ülkemiz taşınmaz değerleme sisteminin mevcut yasal, kurumsal ve teknik yapısı, etkinlik değerlendirmesi ve sistemin yeniden yapılandırılması ihtiyacı özetlenmektedir.

\subsection{Yasal Yapı}

Ülkemizde taşınmaz değerleme alanında uyulması gereken kurallar, farklı mevzuat düzenlemelerinde tanımlanmıştır (Çete, 2008; Köktürk ve Köktürk, 2015; Candaş, 2012; Yomralığlu vd., 2011). Ülkemizdeki değerleme mevzuatı incelendiğinde; değerlemeyle doğrudan ilgili toplam 23 yasa, KHK ve tüzük bulunduğu, dolaylı hükümler içeren mevzuatın da eklenmesi durumunda bu rakamın daha da arttığı görülmektedir. $\mathrm{Bu}$ kanunlarda geçen ifadeler arasında da sağlıklı bir ilişki bulunmamaktadır. Bunun sonucunda da, aynı taşınmaz için gerçekleştirilen farklı değerlemelerde büyük değer farklılıkları ortaya çıkmaktadır (Yomralığ̆lu vd. 2011; Yomralığlu, 2000). 
Ülkemizde birçok uygulamada taşınmaz değerlemesi yapılmaktadır (Candaş, 2012). $\mathrm{Bu}$ uygulamalar genel olarak; emlak vergisi toplama, kamulaştırma, taşınmaz yönetimi, satış veya kiralama bedellerinin belirlenmesi gibi taşınmazlarla ilgili faaliyetlerdir (Yomralığlu vd., 2011). Farklı yasalarda değerlemenin yasal dayanağının 2942 sayılı Kamulaştırma Kanunu olduğu konusunda hükümler yer almaktadır (Köktürk ve Köktürk, 2015; Candaş, 2012; Yomralıoğlu vd., 2011). Kamulaştırma Kanunu'nda taşınmaz mal veya kaynağın değerinin hangi unsurlara göre ve kimler tarafından belirleneceği düzenlenmektedir. Kamulaştırma ile mülkiyet hakkına el koyulduğu için burada taşınmazın değerinin doğru ve objektif şekilde belirlenmesi, mal sahibinin haklarının korunması ve güveninin sağlanması büyük önem arz etmektedir (Yomralığlu , 1997; Candaş, 2012).

\subsection{Kurumsal Yapı}

Ülkemizde kamu alanındaki taşınmaz değerleme çalışmaları, 26 farklı kurumun bünyesinde oluşturulan değer takdir komisyonlarınca gerçekleştirilmektedir. Ayrıca, değerlemeyle ilgili hususlarda yargıya intikal etmiş anlaşmazlıkların çözümü için, ilgili mahkemelerce oluşturulan bilirkişi komisyonları da değerleme yapmaktadır (Çete, 2008, Nişanc1, 2005). Komisyonların oluşturulma şekilleri ve değerlemenin ne şekilde yürütüleceği, uygulamanın amacina göre, farklı yasa ve yönetmeliklerde tanımlanmıştır. $\mathrm{Bu}$ bağlamda, değeri belirlenecek taşınmazın cins ve niteliğine göre, komisyonlarda yer alan üyelerin meslek disiplinlerinin de değiştiği görülmektedir. Kamu kurumları dışında, değerleme yapan "özel sektör taşınmaz değerleme şirketleri” de bulunmaktadır (Çete, 2008, Köktürk ve Köktürk, 2015; Açlar ve Çağdaş, 2008; Yomralığlu, 1995).

Ülkemizde taşınmaz değerleme faaliyeti yürüten farklı kurumlar bulunmakla birlikte, bu alanda ilk akla gelen kurum Sermaye Piyasas1 Kurulu'dur. Sermaye Piyasas1 Kurulu (SPK), 1981 y1lında 2499 sayılı Sermaye Piyasası Kanunu ile kurulmuştur. Kurul, gayrimenkul değerleme şirketlerini listeye alma görevinin yanında, şirketlerin değerleme faaliyetlerini, istihdam edecekleri yeterli bilgi ve tecrübeye sahip "Değerleme Uzmanları" tarafindan yürütebilmelerini sağlamak için, "Değerleme Uzmanlığı Lisansı" verme faaliyetlerini de yürütmektedir (Nişancı, 2005; SPK, 2001; URL_1).

Ülkemizde taşınmaz değerleme uzmanlarının yetiştirilmesi bağlamında yaşanan bir diğer önemli gelişme ise, 21.02.2007 tarihinde tüzel kişiliğe haiz kamu kurumu niteliğinde bir meslek kuruluşu olan "Türkiye Değerleme Uzmanları Birliği”nin (TDUB) kurulması olmuştur. Birlik, 26.05.2010 tarihinde gerçekleşen kuruluş genel kurulundan sonra faaliyetlerine başlamıştır (Açlar ve Çağdaş, 2008). TDUB; gayrimenkul piyasasının ve gayrimenkul değerleme faaliyetlerinin gelişmesini, Birlik üyelerinin dayanışma ve değerleme faaliyetlerinin gerektirdiği özen ve disiplin içinde çalışmalarını, üyelerin mesleki menfaatlerinin korunmasını, haksız rekabetin önlenmesini, mesleki konularda üyelerin aydınlatılmasını ve eğitilmesini sağlamak üzere verilen görevleri yerine getirmektir (URL_2).

Yine ülkemizde, değerleme uzmanları tarafindan, değerleme uzmanlığı mesleğini geliştirmek amaciyla 04 Nisan 2001 tarihinde Değerleme Uzmanları Derneği (DUD) kurulmuştur. DUD, 23 Temmuz 2001 tarihinde Bakanlar Kurulu karariyla "Uluslararası Faaliyet Gösterme" yetkisi çerçevesinde, TEGoVA'ya (The European Group of Valuers) oybirliği ile asil üye seçilerek Türkiye'yi temsil etme yetkisini kazanmıştır. Dernek, Ağustos 2001'de, SPK'nın değerleme uzmanlığı lisanslaması ve değerleme hizmeti verecek şirketlere ilişkin tebliğleriyle (Seri VIII No: 34-35) ülkemizde düzenleyicilik görevini üstlenmiş ve "Değerleme Uzmanlığı" mesleğinin yasal olarak tanınmasını sağlamıştır. Kasım 2002'de Birleşmiş Milletler'in Değerleme organı olan Uluslararas1 Değerleme Standartlar Komitesi'ne (International Valuation Standards Committee, IVSC) oy birliği ile asil üye statüsünde kabul edilen DUD, ABD'de faaliyet gösteren Değerleme Enstitüsü (Appraisal Institute, AI) gibi diğer uluslararası kurumlarla da ilişkiler yürütmektedir (URL_3).

Tapu ve kadastro işlemleri sırasında da taşınmazın asgari emlak değerinden az 
olmamak koşuluyla harç kesilmektedir. Vergi değeri belli olmayan taşınmazlara, kadastro ve dava harc1 ile yargılama giderlerine esas olmak üzere kadastro komisyonunca kıymet takdir edilmektedir (Yomralığlu vd., 2011; Nişanc1, 2005).

Ülkemizde taşınmaz değerlerine ihtiyaç duyulan en önemli uygulamalardan birisi de konut finansmanı için kullanılan tutulu satış (mortgage) sistemidir. Bankalar, katılım bankaları ve finansman şirketleri, tüketiciye konut kredisi kullandırmak amacıyla özel sektör değerleme şirketlerine taşınmaz değerlemesi yaptırmaktadırlar.

\subsection{Teknik Yapı}

Ülkemizde emlak vergilendirmesi amaçlı değerleme çalışmaları Belediyeler tarafından cadde-sokak bazında gerçekleştirilmektedir. $\mathrm{Bu}$ değerleme yaklaşımı, aynı cadde-sokakta bulunan bütün taşınmazların aynı değere sahip olduğu öngörüsüne dayanmaktadır (Aydınoğlu, 2009).

Ülkemizde taşınmaz karakteristikleri ve emsal satışlar veritabanları bulunmamaktadır. $\mathrm{Bu}$ nedenle değerleme faaliyetlerinde ihtiyaç duyulan veriler farklı kurumlardan toplanmaktadır. Ayrıca, değerlemenin teknik boyutunu detaylı bir şekilde düzenleyen mevzuat da mevcut olmadığından, değerleme faaliyetleri bilimsel ve standart tanımlamalardan çok değerleme uzmanlarının deneyimleriyle gerçekleştirilmektedir.

Değerleme çalışmalarının en önemli sonuç ürünlerinden biri değer haritalarıdır. Değerleme alanında iyi uygulamaya sahip ülkelerde bu haritalar üretilmekte ve kullanıcılara sunulmaktadır. Ülkemizde ise, bazı akademik/bilimsel çalışmalar haricinde bu alanda kapsamlı bir çalışma mevcut değildir.

Taşınmaz değerinin belirlenmesinde standart modellerden söz etmek zordur. Her ülkenin taşınmaz değer tespitinde kendine has kültür ve konumsal ya da bölgesel özellikleri nedeniyle kullandıkları yöntemlerde farkl11ıklar görülebilir. Yöntemlerin çoğu emsal karşılaştırma temeline dayanmaktadır (Yalpır, 2007; Pagourtzi and Assimakopoulos, 2003). Temelde üç tip değerleme yöntemi vardır. Bunlar; Emsal Karşılaştırma Yönetimi, Gelir Kapitalizasyon Yöntemi ve Maliyet Yöntemi'dir. Taşınmaz değerleme yöntemleri Şekil 1'de görüldüğü gibi gruplandırılabilir.

Gelişen teknolojiyle birlikte dünyada olduğu gibi ülkemizde de modern değerleme yöntemlerinin kullanılması zorunlu hale gelmiştir. Taşınmaz değerlemede son y1llarda tercih edilen modern değerleme yöntemleri arasında yapay sinir ağları, bulanık mantık, konumsal analiz ve destek vektör makineleri regresyonu gibi yöntemler önemli bir yer tutmaktadır. İstatistiki (stokastik) değerlemenin esasını, taşınmaz değeri ve taşınmaz kriterleri arasındaki sayısal ya da oransal bağıntılar ile matematiksel model oluşturmaktır. İstatistiki yöntemlere göre taşınmaz değerlemesinde en çok kullanılan yöntemler çoklu regresyon, hedonik yaklaşım ve nominal yöntem olarak sıralanabilir. İstatistiki değerleme yöntemleri, hem geleneksel hem de ileri değerleme yöntemlerinin içinde ifade edilebilen yöntemlerdir (Yalpır, 2007).

Toplu değerleme, belirli bir grup taşınmazın aynı zamanda top yekün değerlerinin belirlenmesi işlemidir. İstatistiksel (stokastik) yaklaşımlar ya da bilgisayar teknolojileri kullanılarak taşınmazların değer tahminlerini yapabilen yöntemler toplu değerleme yöntemleri olarak adlandırılmaktadır. Toplu değerleme; vergilendirme ve kamulaştırma gibi aynı anda birden çok taşınmaza değer biçilmesi gerektiği durumlarda, oluşturulan değerleme modeli ile örneklem kümesi üzerinde yapılan istatistik testlerle edinilen bilgileri kullanılarak belirli bir zaman için değerleme kümesine değer biçen, işlemlerin istatistiksel testlerle denetlendiği değerleme sürecidir (Yılmaz, 2010; Yalpır ve Özkan, 2008). 


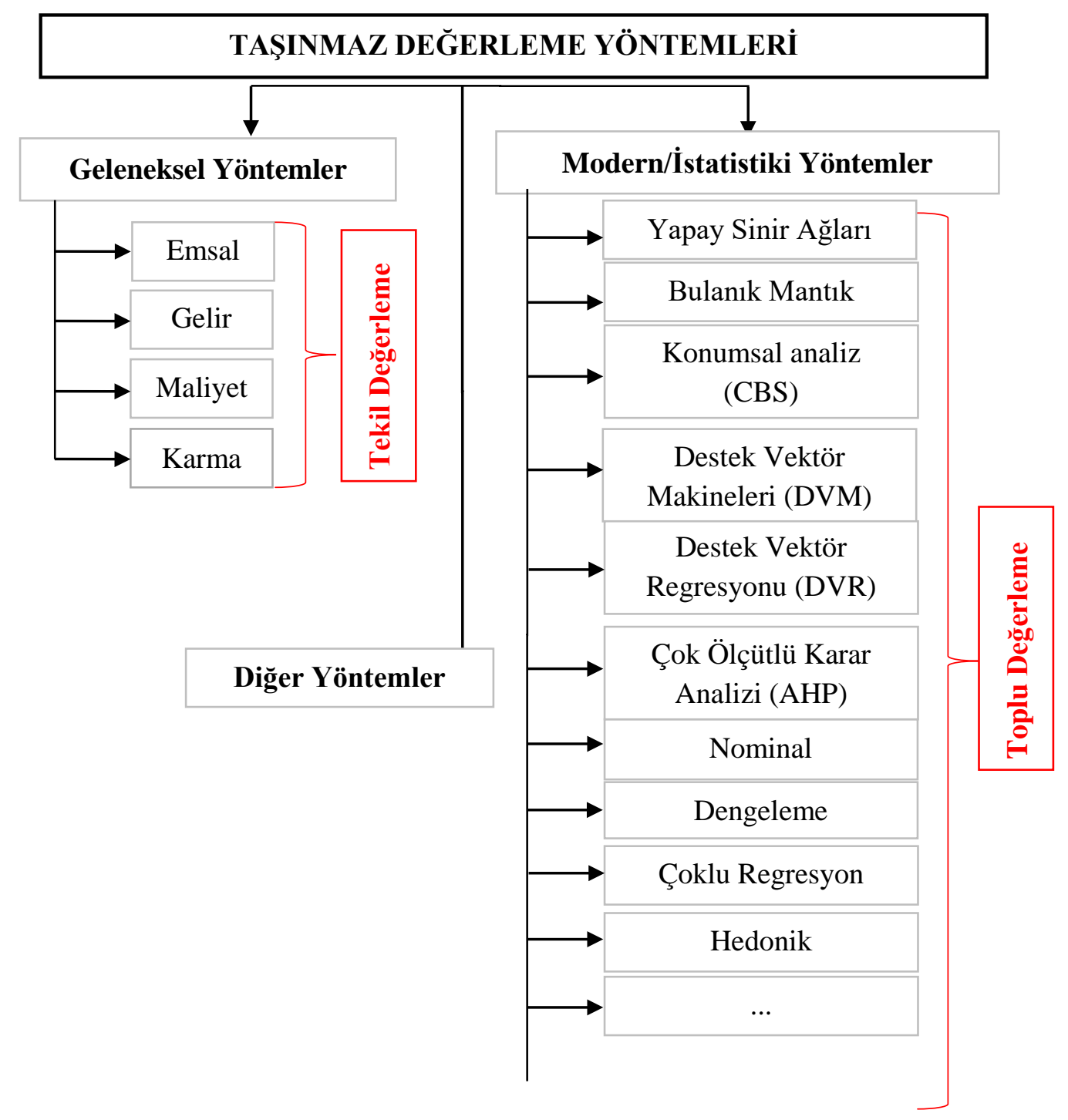

Şekil 1. Taşınmaz Değerleme Yöntemleri (Yalpır, 2007'den Geliştirilmiştir).

Ağaçları ve Lineer Modelleme yöntemleri kullanılmıştır. Aynı veri üzerinde farklı yöntemler uygulanarak gerçekleştirilen modelleme çalışmaları sayesinde; farklı yöntemlerle elde edilen sonuçların birbiri ile karşılaştırılması, toplu değerleme çalışmalarında son yıllarda yeni kullanılmaya başlanan yöntemlerin aynı proje kapsamında uygulanması ve pilot uygulama neticesinde elde edilen sonuçların daha zengin ve anlamlı olması sağlanmıştır. Çalışma kapsamındaki taşınmazlar için hesaplanan değerler ile mevcut harç ve vergi değerleri arasında 2-3 kat farklılık olduğu görülmüştür (TKGM, 2014).

\section{Taşınmaz Değerleme Sistemimizin Etkinliği}

Taşınmaz değerleme sistemimizin etkinliği araştırması, değerleme faaliyeti yürüten kurumların idareci ve çalışanları yanında, özel sektörde faaliyet yürüten değerleme uzmanları ile yapılan mülakatlarla gerçekleştirilmiştir. $\mathrm{Bu}$ çerçevede 12'si genel müdürlük ve muadili kurumlarda olmak üzere toplam 71 mülakat gerçekleştirilmiştir. Görüşme yapılan kişilerden, değerlemeyle ilgili faaliyetleri sırasında yaşadıkları "mevzuat", "kurumsal" ve "teknik" sorunları ifade etmeleri istenmiştir. Mülakatlar sırasında ifade edilen mevzuat sorunları şu şekilde özetlenebilir:

- Değerleme yasamız bulunmamaktadır. İlgili yasal mevzuatta boşluklar mevcuttur.

- Ülkemizde farklı kanun, yönetmelik ve tebliğlerde taşınmaz değerlemesiyle ilgili 
düzenlemeler bulunmaktadır. Ancak, bunların çoğunda değerleme işlemlerinin kural ve standartlarını belirleyen bir düzenleme yoktur. Sadece taşınmazın değerini kimlerin belirleyeceği ve hangi yöntemlerin kullanılabileceğine dair bazı hükümler vardır.

- Genel merkezleri İstanbul ve Ankara gibi büyük şehirlerde bulunan bazı değerleme şirketleri, özellikle diğer şehirlerdeki değerleme faaliyetlerini, lisanslı değerleme uzmanı sayısındaki yetersizlik nedeniyle "çözüm ortakları" eliyle gerçekleştirmektedirler. Ancak, bu çözüm ortaklarının niteliklerini (SPK lisanslı olması gibi), belirleyen herhangi bir hukuki düzenleme bulunmamaktadır.

Taşınmaz değerleme faaliyetlerinin gerçekleştirilmesi sırasında karşılaşılan kurumsal sorunlardan başlıcaları ise şunlardır:

- Ülkemizde doğrudan veya dolaylı yollarla taşınmaz değerlemesi yapan birçok kurum bulunmasına karşın, bu alandaki çalışmaların organizeli bir şekilde yürütüldüğü etkin bir kurumsal yapılanma bulunmamaktadır.

- Değerlemede ihtiyaç duyulan verilerin çoğu Belediyeler, Tapu ve Kadastro Müdürlükleri gibi kamu kurumlarında bulunmaktadır. Ancak, ilgili kurumların bu verileri paylaşmak istememeleri veya verilerin doğru ve güncel olmaması gibi sorunlar yaşanmaktadır.

- Kamu kurumlarındaki taşınmaz değerleme faaliyetleri, kurum bünyesinde oluşturulan komisyonlar eliyle gerçekleştirilmektedir. Ancak, bu komisyonların yapisının homojen olmamas1, üyelerin herhangi bir uzmanlık belgesine veya değerleme hakkında yeterli bilgiye sahip olmamaları gibi nedenlerden dolayı, yapılan çalışmaların geneline itiraz edilmekte ve yargıya taşınmaktadır.

- Ülkemizdeki değerleme uzmanları, piyasadaki mevcut mühendislik-mimarlık büroları veya şirketleri gibi çalışamamaktadırlar. Ferdi olarak şirket veya büro adı altında çalışmak ve bağımsız olarak kamu ve özel sektöre hizmet vermek istemektedirler.

Mülakatlar sırasında ifade edilen teknik sorunlar ise şu şekilde özetlenebilir:

- Ülkemizde değerleme alanında sağlıklı bir sistem, veritabanı, değerleme standartları ve sonuç ürün olan değer haritaları bulunmamaktadir.

- Kurum ve kuruluşlardan veri temini bağlamında kapsamlı bir mevzuat düzenlemesi bulunmamaktadır. Değerleme uzmanlarının tapu sicil müdürlüklerinden veri temini için bazı düzenlemeler getirilmiş olsa da, TAKBIS'ten olması gerektiği ölçüde faydalanılamamaktadır.

- Harç yatırma ve tapu kaydı inceleme gibi işlemler çevrimiçi (online) sistemlere bağlanmaya çalışılsa da mevcut sorunların çözümü anlamında etkin sonuçlara ulaşılamamaktadır.

- Tapu Sicil Müdürlüklerinde yapılan taşınmaz alım-satım işlemlerinde, satış bedeli olarak piyasa değerinin çok altında kalan emlak beyan değerleri esas alınmaktadır.

- Emlak beyan değerlerinin 4 yilda bir güncellenmesinden dolayı şehirlerin hızlı gelişen veya yeni gelişim bölgelerinde daha kısa sürelerde güncelleme yapılamamaktadır.

- Aynı taşınmaz için kurumların bünyesinde oluşturulan kıymet takdir komisyonlarınca belirlenen değerlerle mahkemelerin oluşturduğu bilirkişi komisyonlarının belirlediği değerler arasında büyük farklar ortaya çıkabilmektedir.

\section{Taşınmaz Değerleme Sistemimizde Yeniden Yaptlanma İhtiyact}

Çalışma kapsamında gerçekleştirilen mülakatlar sırasında, taşınmaz değerleme sistemimizde yeniden yapılanmaya ihtiyaç duyulup duyulmadığı hususunun belirlenebilmesi için, değerleme uzmanlarına bir takım sorular da yöneltilmiştir. Örneğin, değerlemeyle ilgili mevcut yasalarda bir belirsizlik veya dağınıklığın olup olmadığ sorusu bunlardan biridir. Bu soruya, 71 mülakatın 65 'inde, "belirsizlik ve dağınıklık var", 5'inde "kismen var", 1 'inde de "yok" cevabı verilmiştir (Şekil 2).

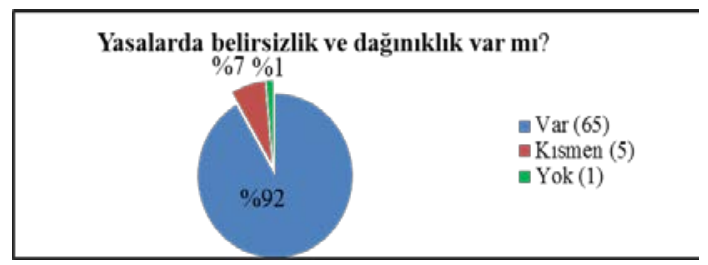

Şekil 2. Taşınmaz Değerleme İle İlgili

Yasalardaki Dağınıklık Durumu. 
Mülakatlar sirasında muhataplara, değerlemeyle ilgili yasaların tek bir "Taşınmaz Değerleme Kanunu" altında toplanmasinın uygun olup olmayacağ 1 sorulmuştur. 71 görüşmenin 67'sinde bu tür bir yasal düzenlemenin yapılmasının gerekli olduğu vurgulanmıştır. Diğer 4 görüşmede ise mevcut mevzuatın yeterli olduğu ve yeni bir yasanın bürokrasiyi daha da arttıracağı görüşü dile getirilmiştir (Şekil 3).

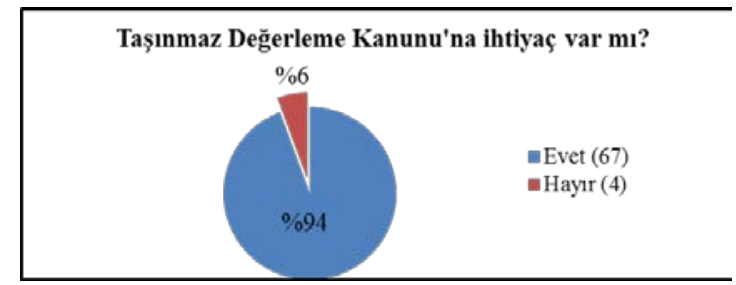

Şekil 3. Değerleme Kanunu İhtiyac1.

Muhataplara değerleme sistemimizde lider kurum yapılanmasına ihtiyaç duyulup duyulmadığ1 sorulduğunda, 71 uzmandan 59'u ülkemizde lider bir değerleme kurumuna mutlaka ihtiyaç duyulduğu, 12'si ise böyle bir ihtiyaç bulunmadığı şeklinde görüş beyan etmiştir (Şekil 4). Lider kurum yaklaşımına olumlu bakmayan uzmanlar; önerilen yapının bir kamu kurumu niteliğinde olmas1 durumunda, sağlıklı bir yapı oluşturulamama riskine vurgu yapmışlar ve bunun yerine sektöre yön verecek böylesi bir yapının, nitelikli ve özerk bir yap1 şeklinde oluşturulması gerektiğini ifade etmişlerdir.

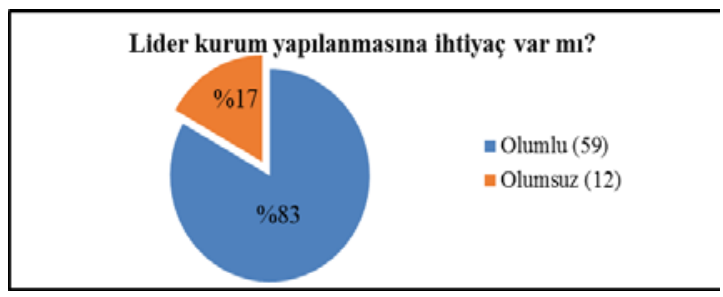

Şekil 4. Taşınmaz Değerleme Sisteminde Lider Kurum İhtiyacı.

Mülakat yapılan kişilere sorulan "Sizce lider kurum hangi kurum olmalı?" sorusuna ise; lider kurumun TKGM olması veya sadece değerleme alanında faaliyet gösterecek yeni bir kurumun yapılandırılması gerektiği şeklinde cevap verildiği görülmüsstür. Mülakatlar sırasında değerlemecilerin SPK ve TDUB ile ilgili görüşleri de alınmıştır. $\mathrm{Bu}$ bağlamda, ilk olarak, "SPK'nın değerleme alanında yürüttüğü faaliyetler” ile ilgili uzman görüşleri sorulmuş, daha sonra da "TDUB'un mevcut yapısı, işleyişi ve bu alanda etkinlik nas1l arttrr1labilir" sorusunun cevab1 araştırılmıştır. Buna göre;

- Gayrimenkul değerleme konusunda hiç eğitim almamış olan kişilere, deneyim şartı olsa dahi, SPK tarafından sadece sinav ile "değerleme uzmanı" ünvanının verilmesi uygun değildir. Değerleme alanında lider bir kurum bulunmadığından, bu gibi sorunlar da çözüme kavuşturulamamaktadır.

- Değerleme faaliyetlerinin lider bir kurum tarafından düzenlenmesi ve yönetilmesi gerekir. SPK tarafindan değerleme alanında yapılan çalışma ve düzenlemeler olumlu özelliklere sahip olsa da yeterli değildir.

- TDUB, kuruluşundan bu yana geçen süre içerisinde kurumsallaşma çabalarına devam etmektedir. Birliğin, SPK'nın desteğiyle kurulmuş olması, değerleme faaliyetlerinde kapsayıc1 rol üstlenmesini engellemektedir.

- TDUB'un, Kanunla kendisine verilen görevleri yerine getirmesi gerekmektedir. Örneğin TDUB'un bugün özellikle sahada çalışan uzmanların işlerini kolaylaştırıcı herhangi bir katkısı bulunmamaktadır.

Sonuç olarak, taşınmaz değerlemenin toplumsal hayattaki giderek artan önemi ve yukarıda bir bölümü özetlenen mevcut değerleme sistemimizdeki sorunlar nedeniyle, ülkemiz değerleme sisteminin yeniden yapılandırılmasına ihtiyaç vardır.

\section{TAŞINMAZ DEĞERLEMESINDE İYİ UYGULAMALAR}

Çalışma kapsamında, taşınmaz değerlemesi alanında iyi uygulamaya sahip bazı ülkelerin değerleme sistemleri mevzuat, kurumsal ve teknik açılardan araştırılmıştır. Ülkemiz değerleme sisteminin yeniden yapılandırılması sırasında bu ülkelerin mevcut sistemlerinin özellikleri yanında, bu sistemlerin gelişim sürecinde elde ettikleri deneyimlerden yararlanılmasi da planlanmıştır. $\mathrm{Bu}$ bağlamda, uluslararası alanda taşınmaz değerlemesinde iyi uygulamaya sahip ülkelerden; Almanya, 
Hollanda, Danimarka, İsviçre, İngiltere ve Amerika Birleşik Devletleri'nin sistemleri üzerine odaklanılmıştır. Ayrıca, Finlandiya, Estonya, Malezya, İspanya ve Tayvan gibi ülkelerin değerleme sistemleri de genel hatlarıyla araştırılmıştır. İyi uygulamalar araştırmasının bulguları aşağıda özetlenmektedir. düzenleyen bir "Değerleme Yasası" veya "Değerleme Tüzüğü" bulunmaktadır. Bazı ülkelerde uygulayıcılara çalışmalarda yol göstermek amaciyla yönergeler, kılavuz dokümanlar veya rehber dokümanlar da sunulmuştur (Çizelge 1). Böylece, değerleme çalışmalarının ulusal bazda tek tipli gerçekleştirilmesi sağlanmaya çalışılmaktadır.

\subsection{Mevzuat}

Araştırma kapsamındaki ülkelerin büyük bir bölümünde, taşınmaz değerleme faaliyetlerini

Çizelge 1. Araştırma Kapsamındaki Ülkelerin Taşınmaz Değerleme Düzenlemeleri (Çete, 2008, Candaş, 2012; Susar, 2007; Susar, 2006).

\begin{tabular}{|l|l|}
\hline \multicolumn{1}{|c|}{ ÜLKE } & \multicolumn{1}{|c|}{ MEVZUAT } \\
\hline Almanya & İmar Kanunu, Taşınmaz Değerleme Tüzüğü, Taşınmaz Değerleme İlkeleri \\
\hline Hollanda & Taşınmaz Değerleme Yasası, Taşınmaz Değerleme Rehberi \\
\hline Danimarka & Taşınmaz Değerleme Yasası, Vergi Yönetimi Yasası, Taşınmaz Değerleme Rehberi \\
\hline İsviçre & Vergi Yasası, Taşınmaz Değerleme Rehberi \\
\hline İngiltere & Belediye Vergi Yasası, Taşınmaz Değerleme Rehberi \\
\hline ABD & $\begin{array}{l}\text { Profesyonel Değerleme Uygulamasının Tek Tip Standartları, Profesyonel } \\
\text { Değerleme Uygulamasının Profesyonel Etik ve Standartları Kılavuzu }\end{array}$ \\
\hline Finlandiya & Değerleme Yönergeleri, Kamulaştırma Kanunu \\
\hline Estonya & Arazi Değerleme Kanunu, Arazi Vergilendirme Kanunu \\
\hline Malezya & Yerel Hükümet Yasası \\
\hline İspanya & Kadastro Yasası, Mortgage Piyasası Düzenleme Yasası \\
\hline Tayvan & Taşınmaz Değerleme Tüzüğü \\
\hline
\end{tabular}

\subsection{Kurumsal Yapı}

Araştırma kapsamındaki ülkelerin değerleme sistemlerinin kurumsal yapıları arasında önemli farklılıklar bulunmaktadır (Çizelge 2). Bu farklar şu şekilde özetlenebilir:

- Almanya'da vergilendirme amaçlı toplu taşınmaz değerleme çalışmaları federal seviyede Maliye Bakanlığı bünyesinde yürütülürken, diğer bütün değerleme çalışmaları iki

temel yap1 tarafından gerçekleştirilmektedir. Bunlar; "Değerleme Uzmanları Komiteleri" ve "Lisanslı Özel Değerlemeciler"dir. Almanya'nın bazı eyaletlerinde, değerleme uzmanları komitelerinin yaptığı çalışmaları denetleyen ve bu çalışmalara yapılan itirazlarda hakemlik görevi gören "Değerleme Uzmanları Yüksek Komitesi" de vardır. Lisanslı özel değerlemeciler, mimar ve taşınmaz birlikleri ile ticaret odası vb. birlik ve odalar tarafindan yetkilendirilmiş uzmanlar olup, komiteler tarafindan da gerçekleştirilebilen pazar değeri sertifikalarının hazırlanması çalışmalarını yürütmektedirler (Çete, 2008, Rissi, 2010; Kertscher, 2007; Seidel, 2005; Rokahr, 1998).

- Hollanda'da temelde vergilendirme amaçli gerçekleştirilen gayrimenkul değerlemelerinden belediyeler sorumludur. Yeterli uzman kadrosu olan belediyeler bu çalışmaları kendileri yürütebilecekleri gibi, bu alanda faaliyet gösteren özel değerleme 
şirketlerinden hizmet satın alma yoluna da gidebilmektedirler. Ülkede ayrıca, değerleme çalışmalarını kontrol eden ve elde edilen deneyimlerin paylaşılmasını sağlayan ulusal bir Taşınmaz Değerleme Konseyi bulunmaktadır (Çete, 2008).

- Danimarka'da ise, temelde vergilendirme amaçlı olarak gerçekleştirilen değerleme çalışmaları, Vergi İdareleri'nin sorumluluğundadır. Danimarka'da bu işlemler, Gümrükler ve Vergi İdaresi'nin 8 alt bölgesinde gerçekleştirilmektedir (Çete, 2008).

- İsviçre'de vergilendirme amaçlı değerleme çalışmaları Kanton Vergi İdareleri'nde gerçekleştirilmektedir. Ayrıca, kanton değerleme uzmanlarının temsilcilerinden oluşan bir de Taşınmaz Değerleme Uzmanları Komitesi bulunmaktadır (Çete, 2008).

- İngiltere'de ise taşınmaz değerleme faaliyetleri, kamu ve özel sektör değerleme örgütlerince gerçekleştirilmektedir. Ülkede, öncelikle, vergiye esas değerleme çalışması yapmak üzere Kamu Değerleme Kurumu (Valuation Office Agency) oluşturulmuş, bu örgütün bütün yerleşim yerlerinde taşra birimi kurulmuştur. Bunun yanında kurumsal bazda uluslararası düzeyde "Uluslararası Değerleme Standartları Komitesi" (IVSC) ve "Lisanslı Değerleme Uzmanları Kraliyet Kurumu" (RICS) da faaliyette bulunmaktadır.

- ABD'deki vergilendirme amaçli toplu değerleme faaliyetleri, Gelir İdaresi Bakanlığı'na bağlı Değerleme Komiteleri tarafindan federal ve eyalet düzeylerinde yapılmaktadır. Ülkedeki değerleme alanındaki tüm işler ve raporlar sürekli olarak Değerleme Enstitüsü (Appraisal Institute) tarafından izlenmektedir.

- Finlandiya'da taşınmaz değer bilgileri kadastro bilgileri arasında yer almakta, bu veriler kadastro kurumu tarafindan üretilmekte ya da ürettirilmekte ve güncellenmektedir. Vergilendirmeye esas toplu değerleme çalışmaları gerçekleştirilmekte ve değerler belli aralıklarla güncellenmektedir. Kamulaştırma çalışmalarındaki değer tespiti de kadastro tarafindan yapılmaktadır. Vergilendirme amaçlı toplu değerleme, her beş yılda bir Ulusal Vergi Kurulu ve Finans Bakanlığ tarafindan, Finlandiya Teknik Araştırmalar
Merkezi (VTT)'ne yaptırılmaktadır. Vergilendirme amaçlı değerleme işlemleri süreci, Vergi Daireleri ve Finans Bakanlığ1 tarafindan yürütülmekte ve Finlandiya Ulusal Arazi Ölçme Kurumu (National Land Survey of Finland, NLS) tarafından tutulan taşınmaz devir fiyat verileri, belediye kayıtları ile pazar verilerinden yararlanılmaktadır (TKGM, 2012).

- Estonya'da 1996 yılından beri taşınmaz hareketleri, veritabanlarında tutulmaktadır. Veritabanlarında yaklaşık 500.000 taşınmaz işlem kayd1 mevcuttur. 2011 yılında gerçekleşen işlem sayısı yaklaşı 42.000 adettir. Alım-satım işlemleri noterler kanalı ile gerçekleştirilmektedir. Ülkede, tekil değerlemelerin tamamı özel sektör tarafindan, toplu değerleme çalışmaları ise kamu ve özel sektör işbirliği ile yürütülmektedir. Değerlemenin kamu bileşeninde sorumlu kurum Estonya Arazi Kurulu'dur (Y1ldı, 2014). Kurul tarafından lisans verilmiş değerlemecilerin listesi, Kurul'un internet sitesinde yayınlanmaktadır.

- Malezya'da Maliye Bakanlığı'na bağlı Gayrimenkul Değerleme Genel Müdürlüğü'nün misyonu; gayrimenkul değerleme ve danışmanlık hizmetlerini sunmaktır. Bunun yanında merkez örgütlenmesinde bilgi teknolojileri birimi adı altında yardıme bir birim daha bulunmaktadır. Taşrada ise, Genel Müdürlüğe bağl1 Eyalet Değerleme Müdürlükleri ve bunlara bağlı Bölge Değerleme Müdürlükleri bulunmaktadır. Kamu ve özel sektörde çalışan tüm değerleme uzmanlarının üye olması gereken Değerleme Şirketleri ve Uzmanları Kurulu adında bir kurul bulunmaktadır. Bu kurula üye olmayan kimselerin değerleme yapması yasaktır (Açlar vd., 2003).

- İspanya'da vergilendirme belediyeler tarafindan yürütülmektedir. Belediyeler yedi homojen ekonomik bölgeye ayrılmıştır (EU, 2004). Değerleme uzmanları kredi veren kuruluş veya değerleme şirketleri tarafından istihdam edilmek zorundadır. Değerleme uzmanlarının mimar veya mühendislik eğitimi almış olma ve özel bir gayrimenkul türünün değerlemesinde (konut gibi) uzmanlaşmış olma şartı vardır. Değerleme şirketleri ve bankaların değerleme birimleri, İspanya Merkez Bankası tarafindan listeye alınmış ve denetlenmektedir. Mesleki sorumluluk 
sigortası zorunludur. Taşınmaz değerleme çalışmalarında toplu değerleme yöntemi esas alınmaktadır (Utkucu, 2007). İspanya'da toplu değerleme sistemi, kapsamlı bir kadastro bilgi sisteminin parçasıdır (Yıldız, 2014; Anonymous, 2002).

- Tayvan'da her ne kadar özel sektör değerleme yapsa da, bu alanda standartları koyan, verileri toplayan, bölgelere göre birim fiyatları belirleyen ve bunları güncelleyen kamu otoritesi Arazi Yönetim Başkanlığı'dır
(Susar, 2006; Susar, 2008). Bu kurum, birçok özelliği ve alt birim yapılanmasıyla, Çete 2008'de önerilen “Arazi İdaresi Müsteşarlı̆̆ı" yapılanmasına benzer özellikler taşımaktadır (Çete, 2008). Tayvan'da Arazi Yönetim Başkanlığı merkez, bölge, il ve ilçeler bazında örgütlenmiş bir kuruluş olup, her il ve ilçedeki Arazi Müdürlükleri (Land Office) eliyle kendisine verilen görevleri yerine getirmektedir (Susar, 2006; Susar, 2008).

Çizelge 2. Araştırma Kapsamındaki Ülkelerin Değerleme Sistemlerinin Kurumsal Yapıları.

\begin{tabular}{|c|c|c|c|}
\hline \multirow[b]{2}{*}{ Ülke } & \multicolumn{3}{|c|}{ Ülkelerin Kurumsal Yapılanma Şekli } \\
\hline & Sorumlu/Yapan & $\begin{array}{l}\text { Denetim ve/veya } \\
\text { Danışmanlık }\end{array}$ & Yardımeı \\
\hline Almanya & $\begin{array}{l}\text { Değerleme Uzmanları } \\
\text { Komitesi }\end{array}$ & $\begin{array}{l}\text { Değerleme Uzmanları } \\
\text { Yüksek Komitesi }\end{array}$ & $\begin{array}{l}\text { Değerleme Uzmanları Komitesi } \\
\text { Lisanslı Özel Değerlemeciler }\end{array}$ \\
\hline Hollanda & $\begin{array}{l}\text { Belediyeler } \\
\text { Polderboard }\end{array}$ & $\begin{array}{l}\text { Taşınmaz Değerleme } \\
\text { Konseyi }\end{array}$ & Özel Değerleme Şirketleri \\
\hline Danimarka & $\begin{array}{l}\text { Gümrükler ve Vergi } \\
\text { İdaresi }\end{array}$ & $\begin{array}{l}\text { Taşınmaz Değerleme } \\
\text { Konseyi }\end{array}$ & Özel Değerleme Şirketleri \\
\hline İsviçre & Vergi İdareleri & $\begin{array}{l}\text { Taşınmaz Değerleme } \\
\text { Uzmanları Komitesi }\end{array}$ & Özel Değerleme Şirketleri \\
\hline İngiltere & $\begin{array}{l}\text { Kamu Değerleme } \\
\text { Kurumu }\end{array}$ & Değerleme Ofisi Ajansı & $\begin{array}{l}\begin{array}{l}\text { Değerleme } \\
\text { (IVSC) }\end{array} \\
\text { Lisanslı Değerleme Uzmanları } \\
\text { Kraliyet Kurumu (RICS) }\end{array}$ \\
\hline $\mathrm{ABD}$ & $\begin{array}{ll}\text { Değerleme } & \text { Kurumu } \\
\text { Belediyeler } & \end{array}$ & Değerleme Enstitüsü & $\begin{array}{l}\text { Değerleme Komitesi } \\
\text { Özel Değerleme Şirketleri }\end{array}$ \\
\hline Finlandiya & $\begin{array}{l}\text { Vergi Daireleri ve } \\
\text { Finans Bakanlığ }\end{array}$ & $\begin{array}{l}\text { Teknik } \quad \text { Araştırma } \\
\text { Merkezi }\end{array}$ & Ulusal Arazi Ölçme Kurumu \\
\hline Estonya & Ulusal Arazi Kurulu & $\begin{array}{ll}\text { Özel } & \text { Değerleme } \\
\text { Şirketleri } & \end{array}$ & Lisanslı Özel Değerlemeciler \\
\hline Malezya & $\begin{array}{l}\text { Gayrimenkul } \\
\text { Değerleme } \quad \text { Genel } \\
\text { Müdürlüğü }\end{array}$ & $\begin{array}{l}\text { Değerleme Şirketleri } \\
\text { ve Uzmanları Kurulu }\end{array}$ & $\begin{array}{l}\text { Lisanslı Özel Değerlemeciler } \\
\text { Özel Değerleme Şirketleri }\end{array}$ \\
\hline İspanya & Belediyeler & Merkez Bankası & $\begin{array}{l}\text { Lisanslı Özel Değerlemeciler } \\
\text { Özel Değerleme Şirketleri }\end{array}$ \\
\hline Tayvan & $\begin{array}{l}\text { Arazi Müdürlüğü } \\
\text { Gayrimenkul } \\
\text { Değerleme Birimi }\end{array}$ & $\begin{array}{l}\text { Arazi } \\
\text { Başkanlığ }\end{array}$ & $\begin{array}{l}\text { Lisanslı Özel Değerlemeciler } \\
\text { Özel Değerleme Şirketleri }\end{array}$ \\
\hline
\end{tabular}

\subsection{Teknik Yapı}

Araştırma kapsamındaki ülkelerin taşınmaz değerleme sistemleri teknik açıdan önemli benzerliklere sahiptir. Bu ülkelerde alım-satım fiyatları envanteri ve taşınmaz karakteristikleri veritabanlarının mevcudiyeti yanında toplu değerleme uygulamalarının değerleme çalışmalarının temelini oluşturması bu benzerlikler arasında yer almaktadır. Araștırma kapsamındaki ülkelerde değerleme faaliyetlerinde kullanılan taşınmaz alım-satım fiyatlarının kaynağını, genelde noterler tarafindan hazırlanan sözleşmeler 
oluşturmaktadır. Bunun dışında bazı ülkelerde kadastro kuruluşları tarafindan üretilen belgeler de kullanılmaktadır (Çizelge 3). Değerlemenin temel bileşenlerinden birini oluşturan alım-satım fiyatlarının doğruluğu ve güncelliği, değerleme sonuçlarını doğrudan etkilediğinden, bu verilerin sağlıklı olmasına önem verilmektedir.
Taşınmaz değerleme çalışmalarının temelini oluşturan girdi verilerinden bir diğeri de taşınmaz karakteristikleridir. $\mathrm{Bu}$ veriler de, araştırma kapsamındaki ülkelerin tamamında, bilgisayar ortamındaki veritabanlarında tutulmakta ve her ülkede değişebilen belli periyotlarda güncellenmektedir.

Çizelge 3. İyi Uygulamaya Sahip Ülkelerde Taşınmaz Alım-Satım Fiyatları Verilerinin Kaynağı.

\begin{tabular}{|l|l|}
\hline \multicolumn{1}{|c|}{ Ülke } & \multicolumn{1}{|c|}{ Taşınmaz Alım-Satım Fiyatları Kaynağı } \\
\hline Almanya & Noterler tarafından hazırlanmakta olan sözleşmeler. \\
\hline Hollanda & Noterler tarafından hazırlanmakta olan sözleşmeler. \\
\hline Danimarka & Belediyelerin değerleme idaresine gönderdiği beyannameler. \\
\hline İsviçre & Noterler tarafından hazırlanmakta olan sözleşmeler. \\
\hline İngiltere & $\begin{array}{l}\text { Lisanslı Değerleme Uzmanları Kraliyet Enstitüsü (RICS) ve Uluslararası } \\
\text { Değerleme Standartları Komitesi (IVSC)'nin ürettiği norm veriler. }\end{array}$ \\
\hline ABD & $\begin{array}{l}\text { Alıcı ve satıcıların beyanları (alım-satım vergileri düşüktür ve yanlış değer } \\
\text { beyanında bulunanlara ağır para cezası öngörülmektedir). }\end{array}$ \\
\hline Finlandiya & Kadastro kuruluşu tarafından üretilen belgeler. \\
\hline Estonya & Noterler tarafından hazırlanmakta olan sözleşmeler \\
\hline Malezya & Malezya Konut Fiyatları İndeksi \\
\hline İspanya & $\begin{array}{l}\text { Kadastro kuruluşu tarafından oluşturulan ya da ürettirilen ve kayıt altına alınan } \\
\text { belgeler }\end{array}$ \\
\hline Tayvan & Arazi Müdürlüğü tarafından üretilen belgeler \\
\hline
\end{tabular}

\section{TÜRKIYYE TAŞINMAZ DEĞERLEME SISTEMI YAKLAŞIMI}

Çalışma kapsamında, gerek değerleme uzmanlarıyla yapılan görüşmeler gerekse iyi uygulamalar araştırmasından elde edilen bulgulardan yararlanılarak, ülkemiz için bir taşınmaz değerleme sistemi yaklaşımı geliştirilmiştir. Türkiye Taşınmaz Değerleme Sistemi (TADES) olarak adlandırılan bu yaklaşımda önerilen mevzuat, kurumsal ve teknik yapı aşağıda özetlenmektedir.

\subsection{Mevzuat}

Ülkemizde; taşınmaz değerleme alanında yaşanan mevcut mevzuat dağınıklı̆̆ının giderilebilmesi, düzenlemelerdeki boşluk ve tekrarların ortadan kaldırılabilmesi, etkin bir değerleme sistemi altyapısının oluşturulabilmesi ve taşınmaz değerleme faaliyetlerinin standart bir yapida gerçekleştirilebilmesi için, "Taşınmaz Değerleme Kanunu" gibi güçlü bir yasal düzenleme oluşturulmasına ihtiyaç vardır. $\mathrm{Bu}$ yasal düzenlemenin, ilerleyen süreçte, Çete 2008'de önerilen “Arazi Kanunu”nun ana bileşenlerinden birini oluşturabileceği de gözönünde bulundurulmalıdır (Çete, 2008). Oluşturulacak yeni politikalar 1şığında taşınmaz değerlemesiyle ilgili mevcut yasalar ve yeni düzenlemeyle ihtiyaç duyulan değişiklikler bir arada değerlendirildiğinde, Taşınmaz Değerleme Kanunu'nun içeriği Şekil 5'de görüldügü gibi yapılandırılabilir. 


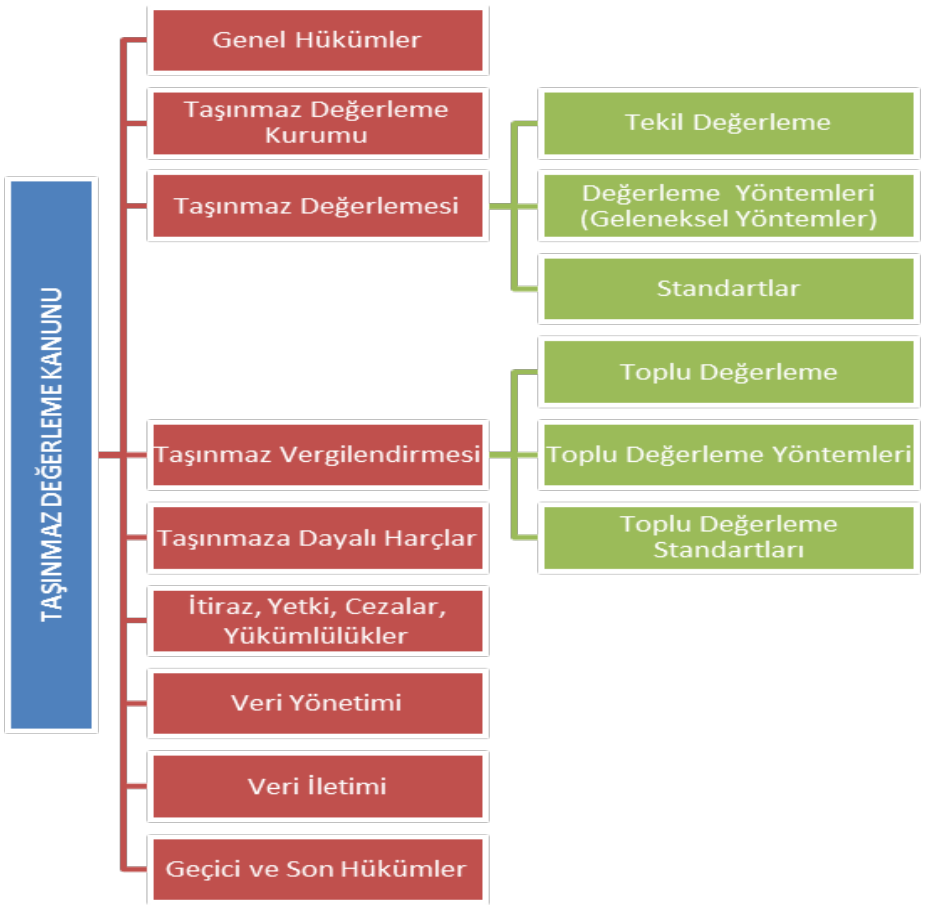

Şekil 5. Önerilen Taşınmaz Değerleme Kanunu'nun içerik özeti

Uluslararası örnekler incelendiğinde, taşınmaz değerlemesinde iyi uygulamaya sahip ülkelerin taşınmaz değerlemesi alanında sağlıklı mevzuat altyapılarının bulunduğu, hem mevzuatlarının hem de yapilan değerleme faaliyetlerinin Uluslararas1 Değerleme Standartları'na (UDES) uygun biçimde ve ülkelerinin koşullarına uygun olarak düzenlendiği görülmektedir (TKGM, 2014). Ülkemizde de SPK tarafindan tebliğ olarak yayınlanan ve değerleme uzmanlarınca bazı çalışmalarda uyulmaya çalışılan UDES'in bir çatı standart olarak kabul edilmesine ve ülkemiz koşullarına uyarlanmasına ihtiyaç vardır. Yeni değerleme mevzuatının da bu kapsamda yapılandırılması önem arz etmektedir. Bu bağlamda TDUB'un Eylül 2011 tarihinde yayınlamış olduğu Türkiye Gayrimenkul Değerleme Standartları (TUGDES) Taslak Raporu çalışmasından faydalanılması doğru olacaktır (Candaş, 2012; TDUB, 2011).

\subsection{Kurumsal Yapı}

Ülkemizde taşınmaz yönetiminde en önemli ve köklü kurumlardan biri Tapu ve Kadastro Genel Müdürlüğ̈̈'dür. Tapu ve Kadastro Genel Müdürlüğü (TKGM); bünyesinde gerçekleştirdiği "Modernizasyon Projesi”nin bir bileşeni olarak yürüttüğü toplu değerleme pilot uygulamalarıyla, bazı çalışanlarını değerleme alanında yüksek lisans ve doktora yapma yönünde teşvik etmesiyle, değerlemeyle ilgili seminer, konferans ve çalıştaylar düzenlemesiyle, bu alanda potansiyel bir lider kurum gibi gözükmektedir. Ancak, TKGM'nin, mevcut yapısıyla bu misyonu üstlenmesi mümkün görünmemektedir. TKGM'yi halihazırdaki faaliyet alanıyla ilgili; (1) tapu kayıtlarının güncellenmesi, (2) intikal işlemlerinin yapılmasının sağlanması, (3) kadastronun sayısal olarak tamamlanmasi, (4) 3B kadastroyla ilgili çalışmaların başlatılması, (5) kamusal hak ve kısitlamaların kadastroda temsil edilmesi, (6) gerçek satış fiyatlarının tapuda kaydedilmesi gibi önemli projeler beklemektedir (Çete, 2008). Dolayısıyla, TKGM'ye ülkenin değerleme faaliyetlerinin düzenlenmesi ve denetlenmesi gibi yeni bir görevin verilmesi çok mümkün görülmemektedir. $\mathrm{Bu}$ nedenle, ülkemizde değerleme faaliyetlerinin sağlıklı ve bütüncül bir yapıda gerçekleştirilebilmesi için değerleme alanında "lider kurum" yapılanmasının oluşturulmasına ihtiyaç vardır.

$\mathrm{Bu}$ bağlamda, Çevre ve Şehircilik Bakanlığı'na (veya yeni ihdas edilebilecek Arazi İdaresi Müsteşarlığı veya Arazi Yönetimi Bakanlığı'na) bağlı Taşınmaz 
Değerleme Genel Müdürlüğü (TDGM) gibi bir kurum oluşturulmalı ve lider kurum bu kurum olmalıdır. TDGM, tüm değerleme faaliyetlerini yönetmeli ve denetlemeli, değerleme çalışmaları ise özel sektördeki değerleme uzmanları eliyle gerçekleştirilmelidir. faaliyetlerinin yerelde yönetim ve denetiminin sağlıklı bir şekilde gerçekleştirilebilmesi için, ihtiyaç duyulması halinde TDGM'ye bağlı bölge ve il müdürlükleri de oluşturulmalıdır. Önerilen TDGM'nin merkez ve taşra teşkilatı yapılanması Şekil 6'da özetlenmektedir.

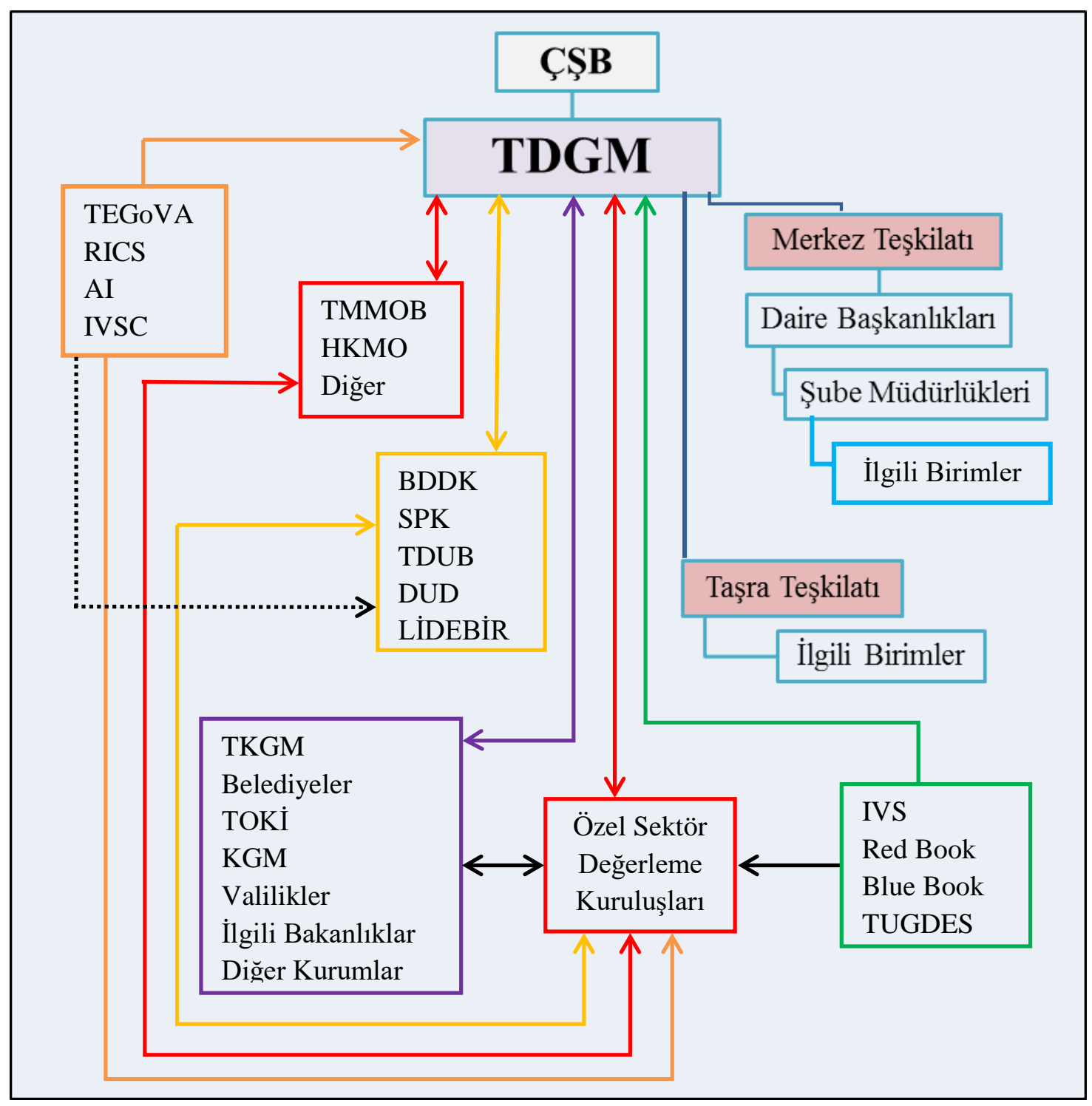

Şekil 6. Türkiye Taşınmaz Değerleme Sistemi İçin Kurumsal Yapılanma Önerisi.

Diğer taraftan, ülkemizde vergilendirme amaçlı toplu değerlemelerin, teknik ve mali altyapısı yeterli belediyelerin bünyelerindeki teknik elemanlarca gerçekleştirilmesi, diğer belediyelerin ise özel sektörden hizmet satın alarak toplu değerleme faaliyetlerini yürütmeleri değerlendirilmelidir. Önerilen
TDGM'nin bölge veya il müdürlükleri, özellikle değerleme faaliyetlerinin yeterli altyapıya sahip belediyelerce gerçekleştirilmesi aşamasında veya özel sektörce gerçekleştirilen değerlemelerinin denetlenmesi sırasında destek sağlayabilir. Bu yaklaşımda, ülkemizdeki özel değerleme 
şirketlerinin nitelik ve niceliklerinin arttırılması önem arz etmektedir. Ayrıca, kamunun ihtiyaç duyduğu kamulaştırma, özelleştirme, vb. amaçlı diğer değerleme faaliyetlerinin de, özellikle değerleme altyapısı yetersiz kurumlarda, hizmet satın alma yoluyla özel sektöre yaptırılması uygun bir yaklaşım olacaktır.

\subsection{Teknik Yapı}

Ülkemiz için önerilen TADES yaklaşımının temel teknik özellikleri şu şekilde özetlenebilir:

- Değerleme uzmanlarının/emlakçıların yaptıkları değerlemeleri/satışları girebilecekleri veritabanları oluşturmalı ve bu veritabanlarının yönetiminin önerilen TDGM'ce gerçekleştirilmesi sağlanmalıdır. $\mathrm{Bu}$ veritabanlarından, sorgulama yapılan taşınmazın satış geçmişine ve verilen tekliflere de ulaşılabilmelidir.

- Değerlemede ihtiyaç duyulan bir diğer temel veri olan taşınmaz karakteristikleri için de veritabanları oluşturulmalı ve bu veritabanlarına da uzmanlar üyelikle veya belli bir ücret karşıllı̆ıında elektronik ortamdan ulaşabilmelidir.

- TAKBİS verilerine erişim daha etkin hale getirilmelidir.

- Diğer birçok ülkede olduğu gibi, ülkemizde de Tapu Sicil Müdürlüklerindeki alım-satım harcı oranları düşük olmalı ve böylece doğru beyanın önü açılmalı, yanlış beyanda bulunanlara ağır para cezaları uygulanmalıdır.

- Değerlemede kullanılan taşınmaz karakteristikleri ve emsal satışlar veritabanları dinamik olarak güncellenmelidir.
- Değerleme işlemlerinin sağlıklı bir şekilde gerçekleştirilebilmesi için, öncelikle, veritabanlarına kaydedilen verilerin güncel, doğru, tam, kapsamlı, anlaşılabilir, kullanılabilir ve erişilebilir olmasına özel önem verilmelidir.

- Değerleme uzmanları veya taşınmaz alımsatımı yapacak kişiler, sorgulama yapılan bölgede satışa sunulmuş taşınmazları da görebilmeli, bölgedeki rayiç fiyatlar hakkında bilgi edinebilmelidir.

- Değerleme işlemleri taşınmazlarla ilgili lisans eğitimi almış; Harita Mühendisliği, İnşaat Mühendisliği, Mimarlık, Şehir ve Bölge Planlama ve Ziraat Mühendisliği gibi meslek disiplinlerince gerçekleştirilmelidir. Değerlemenin en önemli verileri arasında yer alan mekansal bilgileri üreten ve yöneten bir meslek dalı olan Harita Mühendisliği, değerleme çalışmalarını organize eden ve yöneten lider disiplin rolünü üstlenmelidir.

- TADES yaklaşımının teknik anlamda önemli özelliği, taşınmaz karakteristikleri ve emsal satışlar veritabanlarının etkin bir şekilde tesis edilmesi ve sürdürülmesinin altyapısını oluşturmasıdır. $\mathrm{Bu}$ bağlamda, yaklaşım kapsamında önerilen TDGM'nin, kurumsal açıdan en temel özelliği, değerleme faaliyetlerini düzenleyen, yol gösteren ve denetleyen olmasıdır (Şekil 9). 


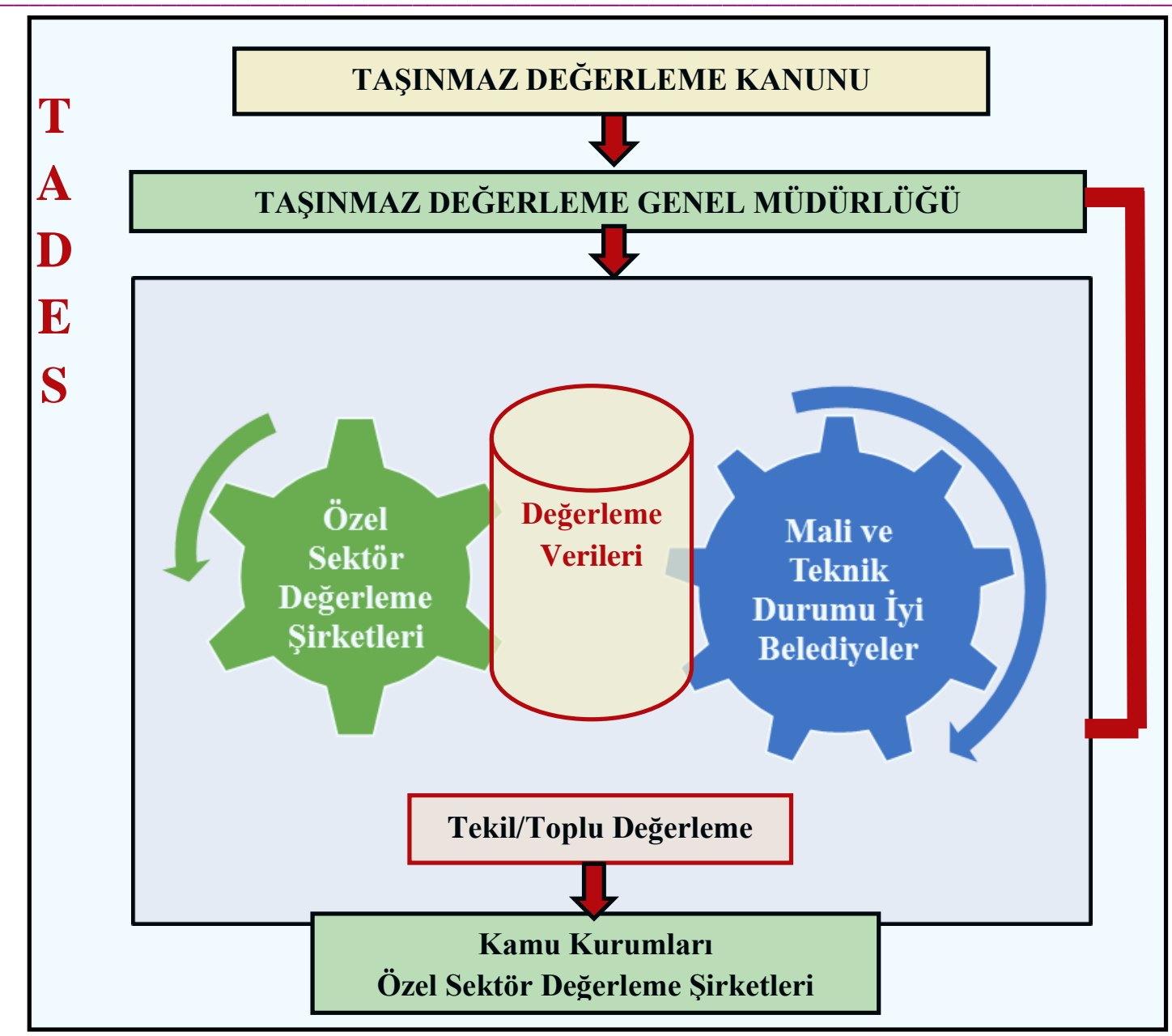

Şekil 9. Türkiye Taşınmaz Değerleme Sistemi (TADES)'in temel mekanizması.

\section{SONUÇ VE ÖNERILER}

İyi işleyen taşınmaz değerleme sistemlerinin tesis edilmesi ve sürdürülmesi, gerek adaletli vergilendirmenin sağlanması gerekse farklı uygulamalarda ihtiyaç duyulan değerlerin sağlıklı bir şekilde oluşturulabilmesi açısından önem taşımaktadır. $\mathrm{Bu}$ bağlamda, makale kapsamında bulguları sunulan çalışmaya, taşınmaz değerleme sistemimizin mevcut mevzuat, kurumsal ve teknik yapısı araştırılarak başlanmıştır. Yapılan araştırmalar sonucunda, taşınmaz değerleme sistemimizde sağlıklı işleyen bir yapıya sahip olmadığımız anlaşılmış, bu nedenle ülkemize özgü bir taşınmaz değerleme sistemi yaklaşımının geliştirilmesi hedeflenmiştir. Türkiye Taşınmaz

Değerleme Sistemi (TADES) olarak adlandırılan bu yaklaşım geliştirilirken iyi uygulamaya sahip ülkelerin sistemlerinden de yararlanılmıştır.

TADES'in mevzuat bileşenine göre; taşınmaz değerleme mevzuatımızdaki mevcut dağınıklığın giderilebilmesi ve iyi işleyen bir taşınmaz değerleme sisteminin altyapısının oluşturulabilmesi için, taşınmaz değerleme faaliyetlerini düzenleyen, yönetmelik ve rehber dokümanlarla desteklenen çerçeve bir "Taşınmaz Değerleme Kanunu"na ihtiyaç vardir.

TADES'in kurumsal yapilanma bileşeninde ise; ülkemizdeki taşınmaz değerleme faaliyetlerinin, Çete (2008)'de önerilen Arazi İdaresi Müsteşarlığı (AİM) veya Çevre ve Şehircilik Bakanlığı'na bağlı olarak tesis edilecek bir Taşınmaz Değerleme Genel Müdürlüğ̈ (TDGM) tarafindan düzenlenmesi, desteklenmesi ve denetlenmesi önerilmektedir. $\mathrm{Bu}$ bağlamda değerleme çalışmalarını gerçekleştiren ağırlıklı olarak özel sektör, yöneten ve kontrol eden de TDGM olmalidır. 
TADES'in teknik bileşenine göre ise; ülkemizde değerleme çalışmaları sırasında ihtiyaç duyulan güncel ve doğru verilere erişilebilmesi ve çalışmaların sağlıklı bir altyapı çerçevesinde gerçekleştirilebilmesi için, taşınmaz karakteristikleri ve taşınmaz alım-satım fiyatları veritabanlarının tesis edilmesi gerekmektedir. Taşınmazlara ait bilgiler sağlıklı verileri içeren ortak bir veritabanından elde edilebilirse, değerleme uzmanları hem ihtiyaç duydukları verilere daha kısa sürede ve kolayca ulaşabilecekler hem de daha sağlıklı sonuçlar elde edebileceklerdir.

Geliştirilen TADES yaklaşımında değerlemeden sorumlu kurum olması önerilen TDGM, farklı kurumların ve özel sektör değerlemecilerinin ihtiyaç duyduğu taşınmaz karakteristikleri ve emsal satışlar veritabanlarının oluşturulmasını sağlamalı ve izlemelidir. $\mathrm{Bu}$ veritabanları, Taşınmaz Değerleme Bilgi Sistemi (TDBS) kapsamında, diğer bilgi sistemleriyle bütünleşik bir veri modelinde ve Coğrafi/Kent Bilgi Sistemi destekli tasarlanmalıdır. Değerleme sonuçlarının kullanıcılara tebliğ edilmesi ve internet üzerinden erişim olanakları hazırlanmalıdır.

Önerilen yaklaşımın hayata geçirilmesiyle, ülkemizde, taşınmaz değerlerinin sağlıklı bir şekilde belirlenmesinin altyapısı tesis edilmiş olacak, adaletli vergilendirme sağlanabilecek, değer tabanlı işlemler sağlıklı bir şekilde gerçekleştirilebilecek ve taşınmaz karakteristikleri ve fiyatları verilerinin ortak veritabanlarında yönetilmesiyle zaman ve maliyet kazanc1 elde edilebilecektir.

\section{TEŞEKKÜR}

Çalışma kapsamında kamu kurumlarında ve özel sektör değerleme şirketlerinde gerçekleştirilen anket ve mülakatlara değerli zamanlarını ayırarak katılan, bilgi ve deneyimlerini paylaşan tüm değerleme uzmanlarına teşekkür ederim.

\section{KAYNAKÇA}

Açlar, A., Demir, H., Çağdaş, V., (2003). Taşınmaz değerleme uzmanlığı ve jeodezi ve fotogrametri (harita) mühendisliği, HKMO Jeodezi, Jeoinformasyon ve Arazi Yönetimi Dergisi, Sayı: 88, 15-20.

Açlar, A., Çağdaş, V., (2008). Taşınmaz (Gayrimenkul) Değerlemesi, TMMOB Harita ve Kadastro Mühendisleri Odas1, ISBN 975-395-551-0, Ankara, $500 \mathrm{~s}$.

Anonymous, UNECE, (2002). The Report of Workshop on Mass Valuation Systems of Land (Real Estate) for Taxation Purposes, Committee on Human Settlements, United Nation Economic Commission for Europe, Geneva.

Aydınoğlu, A., Ç., (2009). Türkiye İçin Coğrafi Veri Değişim Modelinin Geliştirilmesi, Karadeniz Teknik Üniversitesi, Fen Bilimleri Enstitüsü, Doktora Tezi, Trabzon, $292 \mathrm{~s}$.

Candaş, E., (2012). Taşınmaz Değerlemesi İçin Mevzuat Altyapısının Modellenmesi, İstanbul Teknik Üniversitesi, Fen Bilimleri Enstitüsü, Yüksek Lisans Tezi, İstanbul, $131 \mathrm{~s}$.

Çete, M., (2008). Türkiye İçin Bir Arazi İdare Sistemi Yaklaşımı, Karadeniz Teknik Üniversitesi, Fen Bilimleri Enstitüsü, Doktora Tezi, Trabzon, $243 \mathrm{~s}$.

EU, (2004). European Union Land Policy Guidelines, Guidelines for Support to Land Policy Design and Land Policy Reform Processes in Developing Countries, EU Task Force on Land Tenure.

Kertscher, D., (2007). Base of transparency in markets of real estate in Germany: purchase price collection and the report of real estate, The XXX FIG General Assembly and Working Week, Hong Kong SAR.

Köktürk, E., Köktürk, E., (2015). Taşınmaz Değerlemesi, Taşınmaz Hukuku - İmar Hukuku - Değerleme Yöntemleri, Seçkin Yayınc1lk, 2. Bask1, Ankara, ISBN 978975-02-312, $1304 \mathrm{~s}$.

Nişanc1, R., (2005). CBS ile Nominal Değerleme Yöntemine Dayalı Piksel Tabanlı Kentsel Taşınmaz Değer Haritalarının Üretilmesi, Karadeniz Teknik Üniversitesi, Fen Bilimleri Enstitüsü, Doktora Tezi, Trabzon, $230 \mathrm{~s}$.

Pagourtzi, E. and Assimakopoulos, V., (2003). Development of real estate evaluation system with the use of G.I.S. technology, In 10th European Real Estate Society 
Conference, ERES: Conference, Helsinki, Finland.

Rissi, S., B., (2010). Entwicklung Türkischer Immobilienbewertungsverfahren, basierend auf den Erfahrungen der Deutschen Wertermittlungsmethoden, Technısche Universität München, Institut für Geodäsie, GIS und Landmanagement Lehrstuhl für Bodenordnung und.

Rokahr, F., (1998). Land registers, multi-purpose cadastre, land appraisal in the Federal Republic of Germany, National Meetings on Immovable, Land Registry and Taxation, Roma.

Seidel, C., (2005). Transparency in the German real estate market, FIG Commission 9, CIREA and HKIS Symposium - Property Valier's fronting the Triple Bottom Lines of Economic, Environment and Social Conflicts, Xian, China P. R.

SPK, (2001). Sermaye Piyasası Mevzuatı Çerçevesinde Gayrimenkul Değerleme Hizmeti Verecek Şirketler İle $\mathrm{Bu}$ Şirketlerin Kurulca Listeye Alınmalarına İlişkin Esaslar Hakkında Tebliğ, Seri: VIII, No: 35, Resmi Gazete Tarihi: 12 Ağustos, Sayı: 24491.

Susar, Ö., (2006). Tayvan'da Gayrimenkul Değerleme: Yurt Dişı Geçici Görev Raporu, TKGM, Ankara.

Susar, Ö., (2007). Malezya'da Gayrimenkul Değerleme: Yurt D1şı Geçici Görev Raporu, TKGM, Ankara.

Susar, Ö., (2008). Ülkemizde Gayrimenkul Değerleme, http://www.vergidunyasi. com.tr/ dergiler.php?id=4957, (E.T.: Eylül 2015).

TKGM Rapor 1, (2012). Çevre ve Şehircilik Bakanlığ 1 Tapu ve Kadastro Genel Müdürlüğü (TKGM), Tapu ve Kadastro Modernizasyon Projesi (TKMP), "Gayrimenkul Değerlemesi Bileşeni" Birinci Çalışma Ziyareti Yurtdışı Görev Sonuç Raporu, Finlandiya ve Estonya.

TDUB, (2011). Türkiye Değerleme Uzmanları Birliği TUGDES taslak çalışması, Versiyon 1, http://www.tdub.org.tr/ images/pdf/ tugdes_taslak_metni.pdf, (E.T.: Kasim 2015).

TKGM, (2014). Tapu ve Kadastro Modernizasyon Projesi Tarafindan Pilot Uygulama Raporu, Eylül, Ankara.

URL_1:http:// www.spk.gov.tr (E.T.: Ekim 2015). URL_1:http:// www.tdub.org.tr (E.T.: Eylül 2015). URL_1: http://www.dud.org.tr (E.T.: Eylül 2015). Yalpır, Ş., (2007). Bulanık Mantık Metodolojisi İle Taşınmaz Değerleme Modelinin Geliştirilmesi ve Uygulaması: Konya Örneği, Selçuk Üniversitesi, Fen Bilimleri Enstitüsü, Doktora Tezi, Konya, 248 s.
Yalpır, Ş., ve Özkan, G., (2008). The usage of artificial intelligence in determining the residential real-estate prices in urban areas and the comparison of valuation methods, FIG Working Week, Stockholm, 14-19 June, Sweden.

Yıldız, Ü., (2014). Gayrimenkul Birimlerinde Kitlesel Değerleme Uygulamaları ve Türkiye İçin Model Önerisi, Ankara Üniversitesi, Fen Bilimleri Enstitüsü, Yüksek Lisans Tezi, Ankara, 227 s.

Yılmaz, A., (2010). Çok Ölçütlü Karar Destek Sistemleri İle Taşınmaz Değerleme ve Oran Çalışması, Yıldız Teknik Üniversitesi, Fen Bilimleri Enstitüsü, Yüksek Lisans Tezi, İstanbul, $194 \mathrm{~s}$.

Yomralığlu, T., (1995). Taşınmazların Değerlendirilmesi, Ders notları, KTÜ, Trabzon.

Yomralığlu, T., (1997). Kentsel Alan Düzenlemelerinde İmar Planı Uygulama Teknikleri, Taşınmazların Değerlendirilmesi ve Kat Mülkiyeti Mevzuat1, Jeodezi ve Fotogrametri Derneği Yayını, No:1, s. 153-169, Trabzon.

Yomralığlu, T., Nişancı, R., Çete, M., Candaş, E., (2011). Dünya'da ve Türkiye'de taşınmaz değerlemesi, Türkiye'de Sürdürülebilir Arazi Yönetimi Çalıştayı, 26-27 Mayıs, Okan Üniversitesi, İstanbul.

Yomralığlu, T., (2000). Coğrafi Bilgi Sistemleri Temel Kavramlar ve Uygulamalar, 1. Baskı, Seçil Ofset, İstanbul.

Utkucu, T., (2007). Gayrimenkul değerlemesinin önemi ve gayrimenkul değerini oluşturan unsurlar, Vergi Dünyası Dergisi, Sayı: 305. 